\title{
STUDI PEMIKIRAN AI FARUQI TENTANG TAUHID ILMU DAN POLITIK
}

\author{
Vialinda Siswati \\ Institut Agama Islam Darullughah Wa Da'wah Bangil \\ Pasuruan Jawa Timur Indonesia \\ Email : vialindasiswati@gmail.com
}

\begin{abstract}
Abstrak
Ismail Raji AI-Faruqi merupakan tokoh dunia Islam yang banyak dikenal dengan teori Islamisasi ilmu pengetahuan, gagasan Al-Faruqi muncul merupakan bentuk kepeduliannya terhadap keilmuan Islam karena saat itu sudah muncul yang dinamakan dikotomi ilmu yang mengelompokkan ilmu Barat dan IImu Islam, Al-Faruqi yang memiliki banyak latar pendidikan dari Barat mencoba memberikan nuansa baru Islam dengan tetap mempelajari keilmuan barat namun memberi nilai-nilai keislaman di dalamnya sebagai tolak ukur keberhasilan ilmu pengetahuan itu sendiri, dan gagasan inipun banyak memunculkan pro kontra pada masyarakat Islam kala itu sehingga sampai membuat dirinya menjadi terkenal di dunia. Selanjutnya Ismail Raji Al-Faruqi memberikan gambaran seharusnya keilmuan itu dengan membuat seakanakan ada rantai di antara ilmu satu dan lainnya yang saling berkaitan tetapi yang menjadi titik utama adalah ilmu tauhid karena menurutnya ilmu ini adalah ilmu yang paling utama sebelum memunculkan ilmu lanjutan seperti contoh ilmu tauhid mampu mempengaruhi pemikirannya hingga membentuk sebuah internalisasi keimanan yang kemudian merambah dalam pengaturan keduniawian sebagai pendukung adalah politik karena memegang peranan penting dalam sebuah sistem dimanapun berada dari politik tersebut memunculkan sebuah pembentukan kepemimpinan yang nantinya menguasai sistem sebuah ketatanegaraan yang selanjutnya akan kembali terhadap kebebasan ilmu itu sendiri yang nantinya akan tetap menjadi dikotomi ataukah memberikan nilai-nilai yang bernuansa Islam.
\end{abstract}

Kata Kunci : Al Faruqi, Tauhid, IImu dan Politik

\section{PENDAHULUAN}

Masalah yang dihadapi umat Islam adalah terjadinya dikotomi pendidikan. Islam dengan pengetahuan modem yang berasal dari Barat. Barat telah mengklaim bahwa pendidikan Barat adalah pendidikan yang maju punya solusi yang membawa cita-cita ke depan. Banyak sarjana-sarjana muslim yang belajar di Barat tidak memiliki otonomi keilmuan tersendiri karena tidak diberi oleh Barat dalam konteks mandiri. Sarjana-sarjana 
itu hanya dapat berbuat hasil-hasil jiplakan dari para ahli Barat. Hal ini disebabkan kekhawatiran mereka akan terjadinya transpormasi ilmu pengetahuan ke dunia Islam.

Setelah tasawuf dan tariqat memasuki dunia Islam seolah-olah pintu ijtihad sudah tertutup, pendidikan Islam tidak menerima inovasi, arahan dari kurikulum pendidikan yang bersifat tradisional mengacu hanya pada hal-hal yang bersifat syari'ah, seolah-olah pengatahuan eksak seperti astronomi, fisika, kimia kedokteran dan lain-lain sebagainya yang telah dipunyai dunia Islam zaman klasik terabaikan.

Hal ini disebabkan tradisi kebudayaan Islam di dalam kurikulum pendidikan tidak lagi dijadikan mata kuliah wajib di perguruan tinggi di madrasah-madrasah sedangkan tradisi Barat di ajarkan dengan konsisten dan penuh keseriusan merupakan bagian dari program inti yang diwajibkan, hal inilah yang mendorong Al Faruqi mengetengahkan ide Islamisasi ilmu pengetahuan. Bagaimana kiprah Al-Faruqi mengemukakan konsepkonsepnya dalam dunia kontemporer.

\section{PEMIKIRAN AI-FARUQI}

Al-Faruqi banyak mengeluarkan gagasan serta pemikiran yang berhubungan dengan masalah-masalah yang dihadapi oleh Umat Islam pada umumnya. Dari berbagai pemikirannya kalau diamati saling memiliki keterkaitan satu sama lain, yang kesemuanya memiliki satu rantai dengan Tauhid. Diantaranya pemikiran Al-Faruqi yang terpenting adalah :

\section{Tauhid}

Masalah terpenting dan menjadi tema sentral pemikiran Islam adalah pemurnian tauhid, karena nilai dari keislaman seseorang itu adalah pengesahan terhadap Allah SWT yang terangkum dalam kalimat syahadat. Upaya pemumian tauhid telah banyak dilakukan oleh ulama terdahulu, Menurut AI Faruqi kalimat "tauhid" tersebut mengandung dua arti yang pertama "nafi" (negatif) dan kedua: itsbat (positif) laa ilaaha (tiada Tuhan yang berhak diibadahi) berarti tidak ada apapun; illaahi (melainkan Allah) berarti yang benar dan berhak diibadahi hanyalah Allah Yang Maha Esa yang tidak ada sekutu bagiNya dan secara terang- Al Faruqi menyebutkan setiap tahyul. Setiap bentuk sihir, melibatkan pelaku atau pemanfaatannya dalam syirik adalah pelanggaran tauhid.

Tetapi tauhid bukan sekedar diucapkan dengan lisan akan keesaan Allah akan kenabian Muhammad SAW. Namun memiliki sebuah konsekuensi aturan hidup dunia yang sumber kebahagiaan abadi manusia dan kesempurnaanya, Lebih dari itu tauhid juga harus merupakan suatu bentuk realitas batin dan keimanan yang berkembang di dalam 
hati. 1 Tauhid juga merupakan prinsip mendasar dari seluruh aspek hidup manusia sebagaimana yang dikemukakan. ${ }^{2}$ bahwa pernyataan tentang kebenaran universal tentang pencipta dan pelindung alam semesta. Tauhid sebagai pelengkap bagi manusia dengan pandangan baru tentang kosmos, kemanusiaan, pengetahuan dan moral serta askatologi memberikan dimensi dan arti baru dalam kehidupan manusia tujuannya obyektif dan mengatur manusia sampai kepada hak spesifik untuk mencapai perdamaian global, keadilan, persamaan dan kebebasan.

Bagi Al-Faruqi sendiri esensi peradaban Islam adalah Islam itu sendiri dan esensi Islam adalah Tauhid atau pengesaan terhadap Tuhan, tindakan yang menegaskan Allah sebagai yang Esa, pencipta mutlak dan transenden, penguasa segala yang ada. ${ }^{3}$ Tauhid adalah memberikan identitas peradaban Islam yang mengikat semua unsur-unsurnya bersama-bersama dan menjadikan unsur-unsur tesebut suatu kesatuan yang integral dan organis yang disebut peradaban.

Prinsip pertama tauhid adalah kesaksian bahwa tiada Tuhan selain Allah, itu berarti bahwa realitas bersifat handa yaitu terdiri dari tingkatan alamiah atau ciptaan dan tingkat trasenden atau pencipta. Prinsip kedua, adalah kesaksian bahwa tiada Tuhan selain Allah, itu berarti bahwa Allah adalah Tuhan dari segala sesuatu yang bukan Tuhan. la adalah pencipta atau sebab sesuatu yang bukan Tuhan. la pencipta atau sebab terawal dan tujuan terakhir dari segala sesuatu yang bukan Tuhan. Prinsip ketiga tauhid adalah, bahwa Allah adalah tujuan terakhir alam semeta, berarti bahwa manusia mempunyai kesanggupan untuk berbuat, bahwa alam semesta dapat ditundukkan atau dapat menerima manusia dan bahwa perbuatan manusia terhadap alam yang dapat ditundukkan perbuatan yang membungkam alam, yang berbeda adalah tujuan susila dari agama.

Prinsip keempat tauhid adalah, bahwa manusia mempunyai kesanggupan untuk berbuat dan mempunyai kemerdekaan untuk tidak berbuat. Kemerdekaan ini memberi manusia sebuah tanggungjawab terhadap segala tindakannya. Keempat prinsip tersebut di atas di rangkum oleh al-Faruqi dalam beberapa istilah yaitu :

a. Dualitas yaitu realitas terdiri dari dua jenis: Tuhan dan bukan Tuhan; Khalik dan makhluk. Jenis yang pertama hanya mempunyai satu anggota yakni

1 Muhammad Taqi, Misbah,.,.Monoteisme Tauhid Sebagai Sistem Nilai dan Akidah Islam. Terjemahan oleh M.Hashem dari At Tauhid or Monotheisme: Asin The Ideological and The Value Systems of Islam. Jakarta: Lenterabastitama, 1996, hIm.34

${ }^{2}$ Ahmad Anis, Reorientasi Of Islamic History: Some Methodological Essues In Islam; Sorce and Porpose og Knowledge IIIT. Herndon: The International Institut of Islamic Thought

3 Al-Faruqi, Tauhid: Its Implementations For Thought And Life. Wynccote USA: The International Institute of Islamic Thought, 1982, hlm.17 
Allah Subhanahuwataala. Hanya Dialah Tuhan yang kekal, pencipta yang transenden. Tidak ada sesuatupun yang serupa dengan Dia. Jenis kedua adalah tatanan ruang waktu, pengalaman, penciptaan. Di sini tercakup semua makhluk, dunia bendabenda, tanaman dan hewan, manusia, jin, dan malaikat dan sebagainya. Kedua jenis realitas tersebut yaitu khaliq dan makhluk sama sekali dan mutlak berbeda sepanjang dalam wujud dan antologinya, maupun dalam eksistensi dan karir mereka.

b. Ideasionalitas merupakan hubungan antara kedua tatanan realita ini. Titikacuannya dalam diri manusia adalah fakultas pemahaman. Sebagai organ dan tempat menyimpan pengetahuan pemahaman mencakup seluruh fungsi sosiologi. Anugerah ini cukup luas untuk memahami kehendak Tuhan melaluin pengamatan dan atas dasar penciptaan. Kehendak sang penguasa yang hams diatualisasikan dalam ruang dan waktu, dia mesti terjun dalam hiruk pikuk dunia dan sejarah serta menciptakan perubahan yang dikehendaki. Sebagai prindip pengetahuan, tauhid adalah pengakuan bahwa Allah, yakni kebenaran (al-alaq), itu ada dan bahwa Dia itu Esa. Pengakuan bahwa kebenaran itu bisa diketahui bahwa manusia mampu mencapainya. Skeptesisme ${ }^{4}$ menyangkal kebenaran ini adalah kebalikan dari tauhid. Sebagai prinsip metodologi, tauhid terdiri dari tiga prinsip: pertama, penolakana terhadap segala sesuatu yang tidak berkaitan dengan realitas, kedua, penolakan kontradiksi-kontradiksi hakiki, ketiga, keterbukaan bagi bukti yang baru dan atau bertentangan. ${ }^{5}$

Implikasi Tauhid bagi teori sosial, dalam efeknya, melahirkan ummah, suatu kumpulan warga yang organis dan padu yang tidak dibatasi oleh tanah kelahiran, kebangsaan, ras, kebudayaan yang bersifat universal, totalitas dan bertanggung jawab dalam kehidupan bersama-sama dan juga dalam kehidupan pribadi masingmasing anggotanya yang mutlak perlu bagi setiap orang untuk mengaktualisasikan setiap kehendak Ilahi dalam ruang dan waktu. ${ }^{6}$

Dengan demikian pentingnya tauhid bagi Al-Faruqi sama dengan pentingnya Islam itu sendiri. Tanpa Tauhid bukan hanya Sunnah Nabi/Rasul patut diragukan dan perintah-perintahNya bergoncang kedudukannya, pranata-pranata kenabian itu sendiri

\footnotetext{
4 Ibid.,

5 Ibid., hlm.42 -43

6 Ibid., hlm 102
} 
akan hancur. Keraguan yang sama yang menyangkut pesan-pesan mereka, karena berpegang teguh kepada prinsip.

Tauhid merupakan pedoman dari keseluruhan kesalehan, religuistas, dan seluruh kebaikan. Wajarlah jika Alah SWT dan Rasulnya menepatkan Tauhid pada status tertinggi dan menjadikannya penyebab kebaikan dan pahala yang terbesar. Oleh sebab itu pentingnya Tauhid bagi Islam, maka ajaran Tauhid harus dimanifestasikan dalam seluruh aspek kehidupan dan dijadikan dasar kebenaran Islam.

Pandangan dunia tauhid Al-Faruqi sebenarnya berdasarkan pada keinginan untuk memperbaharui dan menyegarkan kembali wawasan Ideasional awal dari pembaharu gerakan Salafiyah, seperti: Muhammad ibnu Abdul Wahab, Muhammad Idris As-Sanusi, Hasan Albana dan dan sebagainya. Landasan dasar yang digunakan olehnya ada tiga yaitu: Pertama, ummat Islam di dunia keadaannya tidak menggembirakan, kedua, diktum Dahi yang mengatakan bahwa "Alah tidak akan mengubah kondisi suatu kaum kecuali mereka mati mengubah diri mereka sendiri (QS. 13-12) adalah juga sebuah ketentuan sejarah, ketiga, Ummat Islam di dunia tak akan bisa bangkit kemabali menjadi ummatan wasa'than jika ia kembali berpijak pada Islam yang telah memberikan kepadanya rasio empat belas abad yang lalu, dan watak serta kejayaannya selama berabad-abad.

\section{Islamisasi IImu Pengetahuan}

Pada hakekatnya ide islamisasi ilmu pengetahuan ini tidak bisa dipisahkan dari pemikiran Islam di zaman moderen ini. Ide tersebut telah diprolamirkan sejak tahun 1981, yang sebelumnya sempat digulirkan di Mekkah sekitar tahun 1970-an. Ungkapan Islamisasi ilmu pengatahuan pada awalnya dicetuskan oleh Syed Muhammad Naguib AlAtas pada tabun 1397 H/1977 M yang menurutnya adalah "desekuralisasi ilmu". Sebelumnya Al-Faruqi mengintrodisir suatu tulisan mengenai Islamisasi ilm-ilmu sosial.

Meskipun demikian, gagasan ilmu keislaman telah muncul sebelumnya dalam karya-karya Sayyid Hossein Nasr. Dalam hal ini Nasr mengkritik epistemologi yang ada di Barat (sains moderen) dan menampilkan epistemology prespektif sufi. Menurut Al-Atas islamisasi ilmu merujuk kepada upaya menggilimunir unsur-unsur, konsep-konsep pokok yang membentuk kebudayaan dan peradaban Barat khususnya dalam ilmu-ilmu kemanusiaan. Dengan kata lain Islamisasi idiologi, makna serta ungkapan sekuler ${ }^{7}$

\footnotetext{
7 Ulumul Qur'an, 1994 hlm.4
} 
Ide tentang islamisasi ilmu pengetahuan Al-Faruqi berkaitan erat dengan idenya tentang tauhid, hal ini terangkum dalam prinsip tauhid ideasionalitas dan teologi. Tuhan dalam penciptaan atau "hukum alam". Dan bila kita kaitkan dengan prinsip teologi artinya dunia memang benar-benar sebuah kosmos suatu ciptaan yang teratur, bukan chaos. Di dalam kehendak pencipta selalu tewujud. Pemenuhan karena pemestian hanya berlaku pada nilai Elemental atau utiliter, pemenuhan kemerdekaan berlaku pada nilai-nilai normal dan bila kita kaitkan dengan Barat maka nilai-nilai ini banyak diabaikan oleh Barat.

Untuk menghindari kerancuan Barat Al-Faruqi mengemukakan prinsip metodologi tauhid sebagai satu kesatuan kebenaran, maka dalam hal ini tauhid terdiri dari tiga prinsip: pertama, penolakan terhadap segala sesuatu yang tidak berkaitan dengan realitas, dengan maksud meniadakan dusta dan penipuan dalam Islam karena prinsip ini menjadikan segala sesuatu dalam agama terbuka untuk diselidiki dan dikritik. Penyimpangan dari realitas atau kegagalan untuk mengkaitkan diri dengannya, sudah cukup untuk membatalkan sesuatu item dalam Islam, apakah itu hukum, prinsip etika pribadi atau sosial, atau pernyataan tentang dunia. Prinsip ini melindungi kaum muslimin dari opini yaitu tindakan membuat pernyataan yang tak teruji dan tidak dikonfirmasikan mengenai pengetahuan. Prinsip kedua yaitu tidak ada kontraksi yang hakiki melindunginya dari kontadiksi di satu pihak, dan paradoks di lain pihak. Prinsip ini merupakan esensi dari rasionalisme. Tanpa ini ia tidak ada jalan untuk lepas dari skepetisme; sebab suatu kontradiksi yang hakiki menandung arti bahwa kebenaran dari masing-masing unsur kontradiksi tidak akan pemah dapat diketahui. Prinsip ketiga tauhid dalam metodologi adalah tauhid sebagai kesatuan kebenaran yaitu keterbukaan terhadap bukti baru dan/atau yang bertentangan, melindungi kaum muslimim dari literalisme, fanatisme, dan konservatisme yang mengakibatkan kemandegan. Prinsip ini mendorong kaum muslimin kepada sikap rendah hari intelektual.

Al Faruqi memaksa untuk mencantumkan dalam penegasan atau penyangkalannya ungkapan wallahu' alam karena ilia yakin bahwa kebenaran lebih besar dari yang dapat dikuasainya sepenuhnya di saat manapun. Sebagai penegasan dari kesatupaduan sumber-sumber kebenaran. Tuhan pencipta alam dari mana manusia memperoleh pengetahuannya. Objek pengetahuan adalah pola-pola alam yang merupakan hasil karya Tuhan ${ }^{8}$. Hal inilah yang banyak dilupakan Barat sehingga timbul ide untuk mengislamisasikan ilmu pengetahuan.

8 Al-Faruqi. Islamization of knowledge: the general principles and the workplan dalam Knowledge for what? Islamabad-Fakistan: National Hijra Council, 1986, hlm.45. 
Islam yang mengadopsi semua ide Barat bahkan kadang-kadang tanpa filter yang akhirnya menempatkan ilmu pengetahuan yang dibangun oleh kesadaran ilahiyah yang kental mengalami proses sukurelisasi yang berobsesi memisahkan kegiatan sekuler dengan kegiatan agama akhirnya mengantarkan ilmuwan pada terlepasnya semangat dari nilai-nilai keagaaman.

Semangat ilmuan moderen (Barat) adalah bahwa di bangun dengan fakta dan tidak ada unsurnya dengan sang pencipta. Kalaupun ilmuan itu kaum beragama, maka kegiatan ilmiah yang mereka lakukan terlepas dari sentuhan semangat beragama. Akhirnya ilmu yang lahir adalah ilmu yang terlepas dari nilai ke-Tuhanan. Dampak yang kemudian muncul ilmu dianggap netral dan bahwa penggunaannya tak ada hubungannya dengan etika.

Menurut Al-Faruqi pengetahuan moderen menyebabkan adanya pertentangan wahyu dan akal dalam diri umat Islam, memisahkan pemikiran dari aksi serta adanya dualisme kultural dan religius. Karena diperlukan upaya Islamisasi ilmu pengetahuan dan upaya itu harus beranjak dari Tauhid. Islamisasi itu pengetahuan itu sendiri berarti melakukan aktifitas keilmuan seperti mengungkap, menghubungkan, dan menyebarluaskannya manurut sudut pandang ilmu terhadap alam kehidupan manusia ${ }^{9}$.

Menurut AI-Faruqi sendiri Islamisasi ilmu pengetahuan berarti mengislamkan ilmu pengetahuan moderen dengan cara menyusun dan membangun ulang sains sastra, dan sains-sains pasti alam dengan memberikan dasar dan tujuan-tujuan yang konsisten dengan Islam. Setiap disiplin harus dituangkan kembali sehingga mewujudkan prinsipprinsip Islam dalam metodologinya, dalam strateginya, dalam apa yang dikatakan sebagai data-datanya, dan problem-problemnya. Seluruh disiplin harus dituangkan kembali sehingga mengungkapkan relevensi Islam sepanjang ketiga sumbu Tauhid yaitu, kesatuan pengetahuan, hidup dan kesatuan sejarah. Hingga sejauh ini kategori-kategori metodologi Islam yaitu ketunggalan umat manusia, ketunggalan umat manusia dan penciptaan alam semesta kepada manusia dan ketundukan manusia kepada Tuhan, harus mengganti kategori-kategori Barat dengan menentukan presepsi dan susunan realita ${ }^{10}$.

Dalam rangka membentangkan gagasannya tentang bagaimana Islamisasi itu dilakukan, Al-Furuqi menetapkan lima sasaran dari rencana kerja Islamisasi, yaitu:

1. Menguasai disiplin-disiplin moderen

\footnotetext{
9 Imanuddin khalil, Pengantar Islamisasi ilmu Pengetahuan dan Sejarah. Jakarta: Media Dakwah 1994, hlm.40

${ }^{10}$ Al-Furuqi, Op.Cit, hlm.34
} 
2. Menguasai khazanah Islam

3. Menentukan relevensi Islam yang spesifik pada setiap bidang ilmu pengetahuan moderen

4. Mencari cara-cara untuk melakukan sentesa kreatip antara khazanah Islam dengan khazanah IImu pengetahuan moderen.

5. Mengarahkan pemikiran Islam kelintasan-lintasan yang mengarah pada pemenuhan pola rancangan Tuhan.

Untuk merealisasikan ide-idenya tersebut Al-Faruqi mengemukakan beberapa tugas dan langkah-langkah yang perlu dilakukan: Tugas petama, memadukan sistem pendidikan Islam dengan sistem sekuler. Pemaduan ini harus sedemikian rupa sehingga sistim baru yang terpadu itu dapat memperoleh kedua macam keuntungan dari sistimsistim terdahulu.

Perpaduan kedua sistim ini haruslah merupakan kesempatan yang tepat untuk menghilangkan keburukan masing-masing sistim, seperti tidak memadainya buku-buku dan guru-guru yang berpengalaman dalam sistim tradisional dan peniruan metode-metode dari ideal-ideal barat sekuler dalam sistim yang dekuler.

Dengan perpaduan kedua sistim pendidikan diatas, diharapkan akan lebih banyak yang bisa dilakukan dari pada sekuler memakai cara-cara sistim Islam menjadi pengetahuan yang sesuatu yang langsung berhubungan dengan kehidupan kita seharihari, sementara pengetahuan moderen akan bisa dibawa dan dimasukkan ke dalam kerangkan sistim Islam ${ }^{11}$.

Bagi Al-Faruqi Islamisasi ilmu pengetahuan merupakan suatu keharusan yang tidak dapat ditawar-tawar lagi oleh para ilmuan muslim. Karena menurutnya apa yang telah berkembang di dunia Barat dan merasuki dunia Islam saat ini sangatlah tidak cocok untuk umat Islam secara menyeluruh. la melihat bahwa ilmu sosial Barat tidak sempurna sudah jelas bercorak Barat dan karena itu tidak berguna sebagai model untuk pengkaji dari kalangan muslim, yang ketiga menunjukan ilmu sosial Barat melanggar salah satu syarat krusial dari metodologi Islam yaitu kesatuan kebenaran. Prinsip metodologi Islam itu tidak identik dengan prinsip relevansi dengan spritual. la menambahkan adanya sesuatu yang khas Islam yaitu prinsip umatiyah.

Untuk mempermudah proses Islamisasi Al-Faruqi mengemukakan langkah langkah yang harus dilakukan diantaranya adalah, Pertama ; penguasaan disiplin ilmu

11 Ibid., hlm. 27 
moderen: penguraian kategoris. Disiplin ilmu dalam tingkat kemajuannya sekarang di Barat harus dipecah-pecah menjadi kategori- kategori, prinsip-prinsip, metodologi-metodologi, problema-problema dan tema-tema.

Penguraian tersebut harus mencerminkan daftas isi sebuah pelajaran. Hasil uraian harus berbentuk kalimat-kalimat yang memperjelas istilah-istilah knis, menerangkan kategori-kategori, prinsip, problema dan tema pokok disiplin ilmuilmu Barat dalam puncaknya.

Kedua ; Survei disiplin ilmu. Semua disiplin ilmu harus disurvei dan di esei-esei harus ditulis dalam bentuk bagan mengenai asal-usul dan perkembangannya beserta pertumbuhan metodologisnya, perluasan cakrawala wawasannya dan tak lupa membangun pemikiran yang diberikan oleh para tokoh utamanya. Langkah ini bertujuan menetapkan pemahaman muslim akan disiplin ilmu yang dikembangkan di dunia Barat. Penguasaan terhdap khazanah Islam. Khazanah Islam harns dikuasai dengan cara yang sama. Tetapi disini, apa yang diperlukan adalah antologi-antologi mengenai warisan pemikir muslim yang berkaitan dengan disiplin ilmu. Penguasaan terhadap khazanah Islam untuk tahap analisa. Jika antologi antologi telah disiapkan, khazanah pemikir Islam harus dianalisa dari perspektif masalahmasalah masa kini.

Penentuan relevensi spesifik untuk setiap disiplin ilmu. Relevensi dapat ditetapkan dengan mengajukan tiga persoalan. Pertarna, apa yang telah disumbangkan oleh Islam, mulai dari Al-Qur'an hingga pemikir-pemikir kaum modernis, dalam keseluruhan masalah yang telah dicakup dalam disiplin-disiplin moderen. Kedua, seberapa besar sumbangan itu jika dibandingkan dengan hasil telah diperoleh oleh disiplin moderen tersebut. Ketiga, apabila ada bidang-bidang masalah yang sedikit diperhatikan atau sama sekali tidak diperhatikan oleh khazanah Islam, kearah mana kaum muslim harus mengusahakan untuk mengisi kekurangan itu, juga memformulasikan masalah-masalah, dan memperluas visi disiplin tersebut.

Penyebarluasan ilmu pengetahuan yang sudah di-Islamkan. Selain langkah tersebut diatas, alat-alat bantu lain untuk mempercepat islamisasi pengetahuan adalah dengan mengadakan konferensi-konferensi dan seminar untuk melibat berbagai ahli di bidang-bidang illmu yang sesuai dalam merancang pemecahan masalah-masalah yang menguasai pengkotakan antar disiplin. Para ahli yangnmembuat harus diberi kesempatan bertemu dengan para staf pengajar. Selanjutnya pertemuan pertemuan tersebut harus menjajaki persoalan metode yang diperlukan ${ }^{12}$.

\footnotetext{
12 Ibid., hlm.61
} 
Adapun menurut Djamaluddin Ancok dan Fuad Nashiru sependapat dengan AlFaruqi, karena menurutnya seorang pemikir akan sangat dipengaruhi oleh ilmu yang dipelajarinya (atau ilmuan yang mendidiknya). Kalau seorang mempelajari ilmu yang berbasis sekularisme, maka sangat mungkin pendangan-pandangan juga sekuler ${ }^{13}$ Adapun penanggap lain adalah Sardar. la menyepakati gagasan yang dikemukakan AlFaruqi. Namun, menurutnya gagasan Al-Faruqi mengandung cacat fundamental. Sardar mengisyaratkan bahwa langkah Islamisasi yang khas terhadap disiplin-disiplin ilmu pengetahuan moderen bisa membuat kita terjebak ke dalam westemisasi Islam. Sebabnya menurut Sardar adalah AI-Faruqi terlalu terobsesi untuk merelevankan Islam dengan ilmu pengatahuan moderen.

Upaya ini dapat mengantarkan pada pengakuan ilmu Barat sebagai standar, dan dengan begitu upaya islamisasi masih mengikuti kerangka berfikir (made of thought) atau pandangan dunia (world view) Barat. Karena itu percuma saja kita melakukan Islamisasi ilmu kalau semuanya akhirnya dikembalikan standanya pada ilmu pengetahuan Barat.

Terlepas dari semua polemik yang terjadi diseputar islamisasi ilmu pengetahuan, sebetulnya islamisasi ilmu pengetahuan yang dimunculkan Al-Furuqi, sebenarnya sederhana saja. Para pendukung ide ini ingin menekankan muatan dimensi moral dan etika dalam batang tubuh ilmu pengetahuan seperti yang dipesankan Al-Qur'an ${ }^{14}$

AI-Faruqi tampaknya melihat bahwa untuk membangun umat tidak dapat dimulai dari titik nol dengan menolak segala bentuk hasil peradaban yang sudah ada. Pembentukan umat malahan harus dilakukan sebagai langkah lanjutan dari hasil peradaban yang sudah ada dan sedang berjalan. Namun, segala bentuk nilai yang mendasari peradaban itu harus ditambah dengan tata nilai baru yang serasi dengan hidup ummat Islam sendiri yaitu pandangan hidup yang bersumber dari AI-Qur'an dan Sunnah.

Al-Faruqi melihat dengan cara seperti ini visi tauhid yang telah hilang akan dapat kembali ke dalam misi pembentukan ummat. Inilah barangkali yang merupakan pokok pemikiran Al-Faruqi dalam bidang pendidikan sebagaimana yang di kemukakannya alam konsep Islamisasi ilmu pengetahuan.

Pengembangan kegiatan ilmuan Islam yang ideal harus didasarkan pada sejumlah asumsi dasar yang Pertama konsep tentang manusia menurut agama Islam sangat lengkap dan lebih baik dari konsep tentang manusia lainnya. Menurut ajaran Islam manusia berkemungkinan untuk menjadi Khalifullah dengan cara menanamkan dan

${ }^{13}$ Djamluddin Ancok, dan Suroso, Nashuri, Fuad. Psikologi Islam, solusi Islam atas Problemproblem Psikologi. Yogyakarta: Pustaka Pelajar, 1994, hlm.14

${ }^{14}$ Amin Abdullah. Filsafat Kalam di Era Post Modernisme. Yogyakarta: Pustaka Pelajar, 1995 
mengamalkan beberapa sifat Tuhan. Oleh karena semua dimensi sifat Tuhan itu tidak terbatas, maka pengembangan aspek moral, spritual dan intelektual manusiapun tidak terbatas. Kedua, oleh karena pengetahuan merupakan kunci kemajuan dan pengembangan tersebut. Maka Islam tidak menghalangi upaya untuk menuntut pengetahuan. Ketiga, pengembangan tersebut harus bersifat menyeluruh mendayagunakan potensi intelektual, pengembangan yang tidak menyeluruh akan menimbulkan ketidakseimbangan. Keempat, aspek spritual, moral, intelektual, imaginative emosional dan fisikal manusia harus diperhatikan dalam upaya pengkaitan berbagai disiplin ilmu. Kelima, pengembangan kepribadian manusia harus dilakukan dalam konteks hubungan manusia dengan Tuhan dan manusia dengan alam Oleh karena itu, penataan disiplin ilmu dan penyusunan pokok batasan harus dirancang dengan mempertimbangkan manusia sebagai individu, manusia sebagai makhluk yang harus hidup berdampingan secara damai dengan alam.

Islamisasi ilmu pengetahuan. Memang terdapat banyak kelemahan struktural dalam pengembangan ilmu dikalangan masyarakat muslim dewasa ini, semua kelemahan tersebut perlu diperbaiki oleh para perancangnya. Para ilmuan muslim menyadari bahwa pengetahuan Barat itu buuruk dan pengetahuan Islam itu baik. Tetapi terlalu sedikit analisis terhadap kemampuan dan karya sendiri. Sebagaimana dikemukakan Ahmad. ${ }^{15}$ Bahwa beberapa ilmuan muslim, misalnya Al-Faruqi menyarankan agar ilmuan sosial muslim memainkan peran revolusioner, dan menghendaki pengembangan peran yang mencakup wilayah agama. Tentu saja pandangan muslim terhadap hal ini, ditentukan oleh sejauh mana pengetahuan mereka tentang masyarakat sebagaimana adanya bukan sebagaimana seharusnya (seperti yang sering dibayangkan oleh para ahli teologi). Selanjutnya gagasan islamisasi ilmu pengetahuan ini lahir karena Al-Faruqi sendiri konsisten dengan konsep tauhidnya dan karena ingin memumikan ajaran tauhid Al-Faruqi menginginkan apa yang dibawa barat tidak harus diterima secara mentah oleh umat Islam. Di samping itu konsep ini muncul karena melihat kondisi obyektif umat Islam yang mengalami kemandegan dalam pemikiran yang disebabkan oleh kolonialisme Barat.

\section{Politik}

Konsep Al-Faruqi tentang politik tidak dapat juga dipisahkan dengan pemikirannya tentang tauhid. Karena menurutnya ummah adalah agen rekontruksi atau

${ }^{15}$ Ahmad Anis, Reorientation of Islamic History: some methodological assues. In Islam; Source and Purpose of Knowledge IIIT. Herndon: The International Institut of Islamic Thought 
pembaruan dunia untuk memenuhi kehendak llahi. Al Faruqi menyebut khalifah Tuhan di alam ciptaan ini ${ }^{16}$. Al Faruqi menekankan bahwa sebagai negara ummah lebih tepat disebut khalifah atau imamah ${ }^{17}$ Ditengah berkembangnya negara-negara nasional di dunia Islam dewasa ini, Al-Faruqi masih mengagungkan gagasan Pan-Islamismenya. menurutnya perkembangan nasionalisme yang berkembang sekarang ini, serta membuat umat Islam terpecah belah. Sampai akhir hayatnya, usahanya untuk mempopulerkan gagasannya ini terus berlanjut. Baginya kekhalifahan adalah bentuk negara Islam yang paling sempurna.

Khalifah adalah prasyarat mutlak bagi tegaknya pradigma Islam di muka bumi. Khalifah adalah induk dari segala institusi, secara internal justifikasi khalifah adalah menguatkan syariah. Secara ekstemal khalidah dapat merespon untuk kebaikan dan keamanan ummat. Mengajak manusia berbuat untuk Tuhannya. Di dalam pemikirannya, negara-negara Islam yang ada sekarang ini akan menjadi propinsi-propinsi yang federal dari sebuah khalifah yang bersifat universal yang harus senantiasa diperjuangkan.

Menurut Al-Faruqi kekhalifahan adalah suatu kesepakatan tiga dimensi: yaitu kesepakatan wawasan yang merupakan komunitas pikiran dan kesadaran, kesepakatan kekuatan mempakan komunitas kehendak dan mempunyai dua komponen, ashabiyah atau sensus komunitas, dimana kaum muslimin menanggapi peristiwa-peristiwa dan situasi dengan cara yang sama, dalam kepatuhan yang padu terhadap Tuhan dan kesepakatan tindakan yang merupakan pelaksanaan dari kewajiban yang timbul dari ijma ${ }^{18}$.

Dengan terbentuknya khalifah, keragaman tidak berarti akan lenyap. Al Faruqi berpendapat bahwa khalifah itu bertanggung jawab melindungi keragaman. Khalifah bahkan wajib melindungi pemeluk agama Kristen, Yahudi karena tidak ada paksaan dalam agama Islam.

Pemikiran tentanng universal Islam yang memberikan pemikiran bahwa Negara Islam tidak terikat oleh suatu tanah atau seseorang. Membatasi negara pada tanah tertentu tidaklah perlu dan tidak universal. Tentu saja Negara Islam harus memiliki tanah dan rakyat hanyalah permulaan. Negara Islami mengupayakan bumi dan keseluruhannya. Negara Islam juga berupaya memberi setiap golongan hak-hak dan kewajiban sebagai

\footnotetext{
${ }^{16}$ Al-Faruqi, Op.Cit, hlm.143

17 Ismail Raji Al-Faruqi, (ed). Historical Atlas of the Religions of Word, New York:Macmillan co, inc. 1974 , hlm. 158

${ }^{18}$ Al-Faruqi, Op.Cit., hlm. $143-148$
} 
warganya. Tanpa kehendak untuk mengembangkan dunia dan program nyata untuk menempatkan setiap tempat manusia, dibawah wewenangnya, dibawah kedamaian dan keadilannya, Negara tersebut kehilangan kekuatan Islaminya. Negara Islami memiliki rakyat. Tetapi rakyat ini tidak berdasarkan kelahiran, warna kulit, ras atau budaya.

Kedaulatan memberikan kekuatan-kekuatan mutlak bersama untuk menentukan menerapkan serta menjadikannya sebagai ukuran puncak perilakunya terhadap mereka dan negara-negara lain, merupakan pertumbuhan lain dari sejarah Eropa. Dalam Islam kedaulatan itu adalah kepunyaan Allah. Dialah yang berhak atau yang berkuasa menentukan kebaikan manusia dan semua makhluk karena semua makhluk adalah milikNya. Pemimpin atau khlifah negara Islami adalah pelaksanaan yang ditunjuk oleh ahli hukum untuk memimpin rakyat dan melaksanakan hukum Allah. Kedaulatan bukanlah milik kelompok, atau golongan tapi ia adalah milik hukum yang menentukan segala hal di dalam dan di luar, dan dibalik itu adalah milik Tuhan.

Kebebasan memiliki hakekat beragama Islam adalah menyadari bahwa kita adalah hamba Allah. Hal ini bertolak dari makna kemakhlukan manusia dengan semua makhluk yang lain. Manusia mempunyai kebebasan dan dapat berbuat lain selain memenuhi kehendak Ilahi. Hanyalah dia yang bebas, tetapi kebebasan itu sendiri untuk memenuhi atau mengingkari ketentuan Ilahi, juga merupakan kehendak ilahi. Kebebasan manusia merupakan karunia termahal dari Allah. Inilah syarat untuk pengabdian manusia kepada-Nya.

Al Faruqi beranggapan sebuah kedaulatan terletak bukan ditangan individu, tetapi ada di tangan Tuhan. Hakimiyah Tuhan itu terwujud melalui syariah, hanyalah Allah semata yang mempunyai hakimiyah dan kemampuan untuk menentukan kebaikan bagi seluruh manusia dan makhluk-makhluk lainnya. Pada kenyataanya, khalifah, terwujud adalah untuk membuat warga negara dapat memenuhi perintah Tuhan. Karena itu, tidak dapat diterima pemisahan antara negara dengan fungsi kepatuhan kepada perintah, kemauan dan kehendak Tuhan.Tetapi hal itu tidak membuat khalifah menjadi sebuah negara Teokrasi, negara di mana Tuhan berkuasa melalui seorang wakil atau kelompok orang tertentu ${ }^{19}$.

\footnotetext{
${ }^{19}$ Al-Faruqi, Op.Cit. Islamization of knowledge, hlm.161
} 


\section{POSISI AI-FARUQI}

Bila dikaji secara seksama pemikiran Al-Faruqi, maka ia tidak terlepas dari rentetan-rentetan sejarah dan pergulatan umat Islam pada masa lalu. Apa yang dikemukakan oleh para pendahulunya dan mencoba mengembangkannya. Sehingga Akbar S. Ahmad menggolongkannya pada golongan tradisionalis. Karena menurutnya bagi para tradisionalis pesan-pesan Islam yang lebih besar jauh lebih penting dari pada pertengkaran personal atau sekterian yang lebih sempit. Mereka percaya pada dialog antar iman.

Tetapi pada satu segi, pemikiran Al-Faruqi sangat modernis (terutama tentang islamisasi ilmu pengetahuan). Maka dalam hal ini penulis lebih cenderung menyebutnya golongan revivalis, kaum revivalis muslim menyatakan bahwa kebangkitan kembali Islam yang tidak hanya bermuasal dari reaksi terhadap Barat, tapi lebih merupakan proses pembaharuan (tajdidi) yang selalu berjalan dan berubah (Islah) sesuai dengan tradisi yang berlanjut terus dalam sejarah Islam itu sendiri. Walaupun demikian, ada berbagai pihak menilai, Al-Faruqi lebih menonjol sebagai aktivis ketimbang pemikir, misalnya gagasannya mengenai islamisasi ilmu dipandang lemah landasan teoritisnya. Juga gagasannya mengenai identifikasi Islam dan Arabisme hal tersebut terlihat dari latar belakang pendidikannya yang cenderung ke Barat.

Ada ilmu yang sesuai dengan Islam dan ada yang tidak sesuai dengan Islam. AlFaruqi adalah termasuk kelompok yang menekankan perlunya Islamisasi ilmu pengetahuan, tipe menurut Sardar ditempatkan sebagai kelompok yang menghubungkan pengetahuan dengan sumber agama Islam yaitu AI-Qur,an dan Hadist. Termasuk dalam kelompok ini adalah Sayyed Hossein Nars, Syed Naguib Al- Attas. Tetapi yang membedakanya adalah dari sisi penekanan ilmu dari masing-masing tokoh. Al-Attas lebih menekan ilmu-ilmu humaniora untuk diislamisasikan. Sedangkan Nasr mencurahkan perhatian pada Islamisasi ilmu-ilmu keamanan. Adapun Al-Faruqi ia lebih menekankan Islamisasi ilmu-ilmu sosial|20

${ }^{20}$ A.M.Saefuddin, Desekularisasi Pemikiran; Landasan Islamisasi, Bandung: Mizan, HIm 280 


\section{Bagan pemikiran Ismail Raji Al Faruqi}

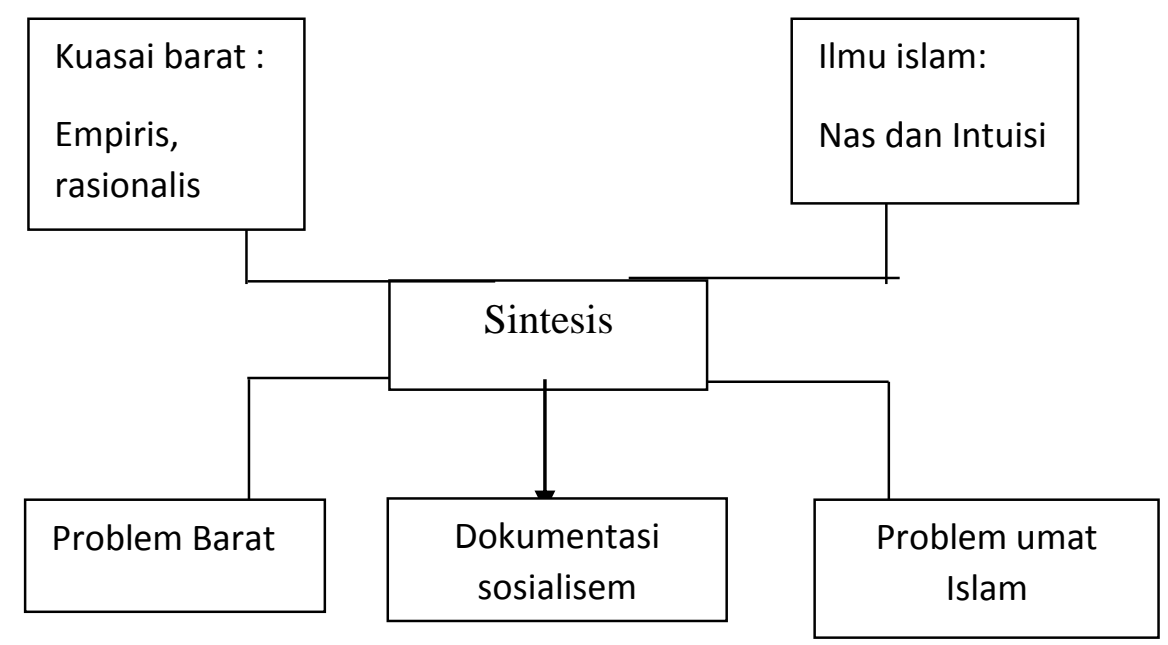

\section{PENUTUP}

Al-Faruqi adalah seorang tokoh yang terkenal dalam Islamisasi ilmu pengetahuan dalam pengembangan pemikiran Islam komtemporer. Gagasan-gagasannya memberikan corak baru dalam keilmuan Islam sehingga mampu memecahkan persoalan yang dihadapi umat Islam akan ketakutan dengan ilmu Barat. Kebesarannya yang langsung berhadapan dengan Barat membuat Al-Faruqi mengamati sendiri tekanan-tekanan barat terhadap dunia Islam dan hal ini memunculkan ide-ide untuk menghadapi pergolakan-pergolakan tersebut. Idenya tidak terlepas dari konsep tauhid, karena tauhid adalah esensi Islam yang mencakup seluruh aktifitas manusia. Begitu pula idenya tentang Islamisasi, tidak terlepas dari pro dan kontra dan telah membawanya pada puncak ketenaran di dunia. 


\section{DAFTAR PUSTAKA}

A.M.Saefuddin, (1997). Desekularisasi Pemikiran; Landasan Islamisasi, Bandung: Mizan Abdullah. Amin, (1995). Filsafat Kalam di Era Post Modernisme. Yogyakarta: Pustaka Pelajar

Al-Faruqi, (ed). (1974). Historical Atlas of the Religions of Word, New York:Macmillan co, inc.

Al-Faruqi, Tauhid, (1982), Its Implementations For Thought And Life. Wynccote USA: The International Institute of Islamic Thought,

Al-Faruqi, Ismail Rji al-, (1986). Islamization of knowledge: the general principles and the workplan dalam Knowledge for what? Islamabad-Fakistan: National Hijra Council,

Anis, Ahmad. Reorientation of Islamic History: some methodological issues. In Islam; Source and Purpose of Knowledge IIIT. Herndon: The International Institut of Islamic Thought

khalil, Imanuddin. (1994), Pengantar Islamisasi ilmu Pengetahuan dan Sejarah. Jakarta: Media Dakwah

Suroso, dkk., (1994). Psikologi Islam, solusi Islam atas Problem-problem Psikologi. Yogyakarta: Pustaka Pelajar.

Taqi, Muhammad Misbah, (1996), Monoteisme Tauhid Sebagai Sistem Nilai dan Akidah Islam. Terjemahan oleh M. Hashem dari At Tauhid or Monotheisme: Asin The Ideological and The Value Systems of Islam. Jakarta: Lenterabastitama 